\title{
Examining the effectiveness of using role- play simulations with Chinese students in China
}

Article

Accepted Version

Toomey, M., Zhou, X. and Yan, X. (2020) Examining the effectiveness of using role-play simulations with Chinese students in China. International Studies Perspectives, 21 (4). pp. 363-378. ISSN 1528-3585 doi:

https://doi.org/10.1093/isp/ekz014 Available at https://centaur.reading.ac.uk/85783/

It is advisable to refer to the publisher's version if you intend to cite from the work. See Guidance on citing.

To link to this article DOI: http://dx.doi.org/10.1093/isp/ekz014

Publisher: Oxford University Press

All outputs in CentAUR are protected by Intellectual Property Rights law, including copyright law. Copyright and IPR is retained by the creators or other copyright holders. Terms and conditions for use of this material are defined in the End User Agreement.

www.reading.ac.uk/centaur 
Central Archive at the University of Reading

Reading's research outputs online 


\title{
Examining the effectiveness of using Role-Play Simulations to teach Comparative Politics to Chinese students.
}

\author{
MICHAEL TOOMEY \\ University of Reading \\ XINHE ZHOU \\ Columbia University
}

AND

XIN YAN

Hong Kong University of Science and Technology

\begin{abstract}
To date, a significant body of literature has been compiled which testifies to the effectiveness of role-play gaming and simulations as pedagogical methods in Political Science. Many of these studies have been based on students with a Western background. In contrast, little research exists on the teaching of political science in China as a whole, never mind on the effectiveness of simulations for teaching Chinese students. This study seeks to investigate the efficacy of role-play simulations as a method for teaching Comparative Politics to Chinese students. Levels of long-term knowledge retention, enthusiasm towards political science, and self-reported learning outcomes are examined among two groups of students. A test group, comprised of students who have completed at least one political science course, participated in a politics-based role-playing simulation. They were compared against a control group, who had also completed the same political science course, but had not participated in a comparable game. It is found that the test group displayed significantly better self-reported learning outcomes, significantly better knowledge retention than the control group (albeit at the $90 \%$ level), and no significant variation in enthusiasm.
\end{abstract}

Keywords: role playing, active learning, comparative politics, China

\section{Introduction:}

In recent years, a growing body of literature has emerged surrounding the use of role-play simulations and games as a tool for political science pedagogy, and attesting to the merits of 'active learning' exercises in a variety of manners. This emergence has coincided with a growing awareness regarding the limitations of the traditional "signature pedagogy" of many political science departments which are typically centered around teacher-centric, lecture-based courses or smaller, student-centric group sessions (Murphy and Reidy 2006), and about the variations in 
student learning styles which can influence educational and pedagogical outcomes (Fox and Ronkowski 1997, 735-736). It is clear that at present, certain limitations exist in terms of the reliability of the data used to test the effectiveness of these simulations and games. For instance, it can be inherently difficult to use controlled experimentation to test the usefulness of simulations as opposed to traditional methods of teaching through lectures and assigned readings (McCarthy 2014, 401-402). Without this, it can be somewhat difficult to isolate what necessarily is the benefit of simulations, and to what extent simulations have added value to a course, which would not otherwise have been added had traditional methods been used only (Baranowski and Weir 2015, 391-392; Stover 2007, 113; Wheeler, 2006a). With that said, a significant and growing number of works, albeit perhaps somewhat tenuously, report that simulations have had positive effects in areas such as student interest and engagement (Weidenfeld and Fernandez 2017, 54-55), student satisfaction and enthusiasm about the respective course (Dougherty 2003, 242-243; Glazier 2011, 376-377), student understanding of theoretical concepts and applications (Langfield 2016, 417; Biziouras 2013, 194), knowledge retention (Switky and Aviles 2007, 399), and so on. Predominantly simulations seem to be used in the more structured and rules-based field of International Relations, although increasingly simulations are used as an active-teaching component in classes on American, European, and Comparative politics (Baranowski and Weir 2015, 394-395). However, broadly speaking, to date the research on the use of simulations tends to be focused on the use of simulations in Western classrooms, and oftentimes in classes that are also being taught to political science major students. Relatively little research exists on the use of simulations in Chinese classrooms, and on the efficacy of using simulations to teach students who do not come from democratic societies, and who may not be expected to have a sophisticated understanding of the various concepts related to politics prior to taking a political science class. While there is not a complete absence of literature on the use of simulations in non-Western classes, it is an under-researched area, especially considering the growing number of political science programs and courses being offered in Asian universities (and the concurrent growth in the number of Western universities creating campuses in the region). Additionally, there is somewhat of a dearth of research on the teaching of political science, broadly speaking, in China.

This article tests this gap by discussing the use of a simulation of a parliamentary election campaign in three sections of an introductory course on Comparative Politics, which was conducted at Wenzhou-Kean University (WKU) in Wenzhou, China during the Fall 2016 semester. It begins by situating the exercise used within the universe of simulations that are used in Political Science classes, and also be establishing the unique pedagogical challenges posed by the teaching of a (stereotypically) Western-oriented subject such as political science in China. It will then describe in detail the manner in which the simulation was carried out, the goals and objectives of the various actors and the specific tasks they were asked to carry out. It will also examine the effectiveness of this method in terms of improving student satisfaction with learning outcomes, encouraging long-term knowledge retention, and evoking enthusiasm towards political science amongst the participants in the simulation. It does this by comparing data drawn from student evaluations of the course and from a post-facto knowledge test taken by a control group (who did not complete the simulation) and a test group (who did complete the simulation). Finally, the article will conclude by drawing inferences and conclusions from the data, and by making some future recommendations regarding the use of simulations as a pedagogical tool in political science. 


\section{Choosing the format: 'games' vs. 'simulations'}

Upon deciding to use simulations as a teaching method, it is broadly agreed that much consideration must be given to the form and structure of the simulation, and that they be designed in an effective manner, with a clear set of learning objectives and goals (Asal and Kratoville 2013, $133,141)$. One of the most important decisions to be made, then, is centered around whether to use a 'game', an abstraction of real-life cases using a fictional setting for the exercise, or a 'simulation', which is much more closely based on real-world events and is usually based in 'reality', or a potential counterfactual reality (Asal and Blake 2006, 2-3; McCarthy 2014, 404-405; Langfield 2016, 404; Gilley 2013, 223-224). These alternatives will lead to different outcomes, and should be used for different purposes; while games are somewhat more suitable to exercises designed to teach students about processes and abstract theoretical concepts and ideas, simulations are more useful for content-oriented outcomes, and for helping students to understand the perspectives, views and objectives of real-life actors (Asal and Blake 2006, 2; McCarthy 2014, 405). Additionally, the level of complexity involved in simulations as opposed to games varies. According to Wheeler (2006b, 333), simulations tend to involve a greater degree of complexity, and to have a wider potential variety of outcomes and interactions between participants. Indeed according to Jones, it is of paramount importance that a simulation feature as little direction from teachers or trainers as possible: “...the survivors must be allowed the opportunity to die, the journalists must be allowed the opportunity to miss the deadline, the cabinet ministers must be given the freedom to fail to discuss the main item on the agenda...if [the simulation] is taught, then it is not a simulation" (Jones 1995, 9). This is a result of the fact that simulations are intended to closely match real-world behavior, with its abundance of possible consequences and results. In contrast, games, whilst still intending to recreate real behaviors and situations, often have much more simple or abstract forms of interaction. Additionally, games are less likely to have real-world ethics; as Jones explains:

"...suppose an event is labelled OUR TOWN DEVELOPMENT GAME and the only roles are property developers, the winner being the group to make the most profit. Afterwards, one group says 'We won because we gained the most profit by building a nuclear plant next to the railway' then they deserve praise not blame; they had behaved responsibly by fulfilling their duty to try to win. But if the roles for the property developers had said something like 'Company reputations matter as well as profits and did not refer to 'winners', then clearly the event was intended to be a simulation since real-world reputations involve real-world ethics" (Ibid., 14-15).

Based on this, we turn to describing the simulation that was run at WKU in Fall 2016. The participants in the simulation were students in three sections of Introduction to Comparative Politics classes, none of whom had taken a political science class prior to that semester. The primary purpose for this simulation was to achieve the following learning outcomes: to help students gain a more tangible and concrete understanding of the relationship between political cleavages and the formation and successes of political parties, the significance of political communication and how parties signal their strategies, and the importance of governmental types (i.e. parliamentary, presidential, semi-presidential etc.) and voting systems (i.e. proportional 
versus majoritarian) in shaping political outcomes. The simulation intended to teach students about the relevance of issues and divisions within a society to party formation and strategies, and to help them to understand how the salience of these parties' platforms to the demands of their electorates will shape and inform their successes. Most importantly, though, this simulation was designed to facilitate active engagement with the processes by which Western democracies come to select their leaders, to encourage longer-term retention of the basic concepts and ideas associated with electoral campaigns, and to promote greater enthusiasm amongst the students towards the study of political science. Given that for many students at WKU, the first political science class they take will often be their last, ${ }^{1}$ these latter objectives are of particular significance. With these learning objectives in mind, then, and with reference to the previously outlined typology, the exercise was designed as an open-ended 'simulation', rather than as a game. The fact that the scenario provided (whereby students are contesting an election in a democratic China, where Communism has never existed, but the country has developed in the exact same manner nonetheless) is fully counterfactual, meant that the focus of the exercise remained on learning about the process of elections and political parties in democratic countries, rather than on learning the specific content of given party platforms. Participants in the simulations were also required to retain some semblance of real-world ethics, so as to ensure a closer approximation of reality. All of these are elements that are more effectively encapsulated in a simulation than in a game. The specific details of the simulation are described fully in the following pages.

\section{The uniqueness of political science education in China}

With this in mind, it is also important to understand and consider the unique pedagogical challenges posed by teaching political science in Chinese classrooms, as opposed to Western classrooms. Indeed, given the cultural and political differences between China and the United States and Europe, a political science instructor is going to be faced with significant challenges in terms of relating what is often (and oftentimes with good reason) consider to be a Western-centric field of study. When it comes to the academic research on the use of simulations in political science classes, it is also quite clear that the prevailing focus of publications to date seem to have been on the use of simulations in Western classrooms and to comparably sophisticated audiences, who can reasonably be expected to have a rounded understanding of many of the basic concepts associated with the study of Political Science and with living in a democratic polity.

If one is to ignore the language barrier, teaching Political Science in a Chinese environment presents unique challenges which are not often faced by academics based in Western universities. While there is a dearth of literature specifically on the teaching political science (as the subject and field is understood in the West) in China, there are several reasons why China provides a

\footnotetext{
${ }^{1}$ As a small Sino-American collaborative university, Wenzhou-Kean University at the time of writing has only eleven major degree programs: English, Graphic Design, Finance, Accounting, Marketing, Global Business, Management, Psychology, Architectural Studies, Computer Science, and Mathematical Sciences. Students take political science courses (amongst others) as part of their general education requirements, and may also take extra courses as free electives. However, the number of students who have taken more than one political science class is typically very low. In the Spring 2017 semester, for instance, only three students were taking a political science class for their second time.
} 
sharply contrasting educational context for one to teach political science in. For one thing, professors in China do not enjoy the same breadth of academic freedom and freedom of speech as their colleagues in the West, as topics such as the 1989 Tienanmen Square massacre, the status of Taiwan, and Tibetan separatism and the Dalai Lama (amongst others) are culturally and politically sensitive subjects which have the potential to offend student sensibilities (at the very least) (Toomey 2017; Luo, 2016; Volodzko, 2015). Additionally, a basic gap exists between the average Western and Chinese citizen regarding the nature and significance of historical and political figures and events. Given the often Euro-centric and Western-centric nature of political science, it is sometimes easy to forget that events and figures that are seen by Europeans as being of eminent importance, may not carry the same (if any) cultural or historical resonance in China (Toomey 2017; French at. al. 2017). And while Chinese students do receive some high-school education on Western political systems, this is largely filtered through a Sino-Marxist perspective, not to mention that its depiction of these systems is somewhat thin, descriptive, and lacking in analytical depth. The most important difference between Western and Chinese education, however, are the political goals that education often explicitly serves in China. Prior to the early 1990s, Chinese high school students would receive instruction in "Marxist political science", which consisted of communist doctrine and propaganda; although this was discontinued, it was replaced with a "patriotic education" program, which sought to build legitimacy and moral authority for the Chinese Communist Party (Zhao 1998, 293; Vickers 2009, 526). Indeed, during the Presidency of $\mathrm{Xi}$ Jinping, such programs have been greatly expanded to include students at all levels of education, and even academics (Jiang 2017; Liu 2018). This in itself is not a feature that is totally unique to China, as other authoritarian countries such as Kazakhstan (Uzakbayeva et. al. 2014, 675) and Russia (Omelchenko et. al. 2015, 364) have patriotic education programs as well. However, the existence of such a feature helps to highlight the stark contextual differences that exist between Western and Chinese educational systems. As a result, when students begin studying subjects such as Comparative Politics at institutions such as WKU with a greater degree of academic freedom and independence than Chinese institutions, it is reasonable to expect that they are starting at the very beginning.

In addition to this, it is clear that the implementation of active-learning strategies in Chinese classrooms cannot be assumed to be effective in the same manner that they have been shown to be in Western classrooms. Chinese norms regarding the appropriate conduct of teaching are quite different to Western norms; traditionally, Chinese teaching follows a teacher-centric model, with a hierarchical relationship existing whereby educators are tasked with imbuing students with knowledge, and students are tasked with following direction and receiving information from the teacher (Liu et. al. 2018, 3; Hu 2013, 2). In concert with this, Chinese students often have a 'passive' learning style, focusing particularly on ensuring that they have sufficiently covered the syllabus to allow them to excel on assessments (Hing Wa Sit 2013, 36-37). While this approach may have its own merits, it also promotes a somewhat subservient relationship between the teacher and the student, and can lead to the problem of students memorizing the facts of a given issue without truly understanding it.

There is some debate in the literature over the efficacy of using active learning methods for novice students. Fox and Ronkowski $(1997,736)$ argue that active learning styles are more 
suitable in classes populated by introductory students and underclassmen, as these groups generally tend to have a greater appreciation for such methods, and active learning has the potential for engaging and interesting a larger audience in political science from an earlier stage of their academic development. Jackson $(2013,218)$, on the other hand, argues that simulations are most effective in classes with a more advanced group of students and upperclassmen, as they are more likely to retain the effects of the simulation (in terms of knowledge retention and understanding) going forward. Likewise, Weidenfeld and Fernandez (2017, 55-57) noted that students with a comparatively higher level of exposure to political science, such as political science majors or upperclassmen, were more likely to evaluate courses using simulations and other forms of roleplay gaming more positively than those from a relatively unsophisticated background. ${ }^{2}$ In designing our simulation, we accept the basic arguments of Fox and Ronkowski whilst remaining aware of the limitations identified by Jackson and Weidenfeld and Fernandez. With this in mind, and also bearing in mind the cultural, social and political differences (outlined above) between Western and Chinese students, it is important to try to accommodate the students and adapt the simulation to match the backgrounds of the students; as Du-Babcock and Babcock $(2000,37)$ argue, such adjustments can more effectively contribute to the success of simulations in Asian classrooms by adding a greater sense of realism and relevancy to proceedings.

\section{Designing and creating the simulation: the 2016 Chinese Parliamentary General Election}

As was mentioned earlier, the distinctions between the various designs of exercises and games that exist are crucial to achieving the respective teacher's intended learning outcomes. In the specific case being examined in this paper, it was decided that what was of primary importance was to allow students develop a more comprehensive and personal understanding of the issues involved in the development of a political party's electoral and political manifesto, such that these concepts would resonate more fully with them in future (rather than if they had merely learned the theory of the subject). The simulation being described here thus aimed to replicate a hypothetical multiparty parliamentary electoral campaign and election in modern China: given the students' lack of detailed familiarity with the issues at stake in other countries, it was decided that the only way of conducting the simulation in such a manner as to develop their understanding of the importance of political cleavages would be to relate it as closely as possible to their own lived experiences.

Students were separated in groups of four or five (depending on the size of the class; four students per group usually worked better) into various different political parties, which were subsequently divided into six broad archetypes: conservative, social democratic, centrist liberal, green, radical right, and radical left. Students were each provided with briefing material on the simulation and on the traditional policy preferences of their parties, and were required to broadly form their party around these preferences. With that said, the various different groups were allowed to shape their party's identities and platforms in a manner that they perceived would be most

\footnotetext{
${ }^{2}$ While these points may be valid and interesting, they do not distract from the basic research purpose of this paper, which is to examine the effectiveness of using role-play gaming and active learning vis-à-vis the traditional methods of read-and-lecture to teach basic concepts of comparative politics to a group of novice Chinese political science students.
} 
relevant to the Chinese 'electorate', and which would give them the best chance of winning the election. As such, the open-endedness of this approach allows for greater flexibility on the part of the students to shape the exercise in a manner that reflects their own lived experience.

Each group was also given four specific roles that they had to fill: party leader, finance and economics spokesperson, justice and home affairs spokesperson, foreign affairs spokesperson, and campaign manager. The party leader was to be the 'public face' of the party, and was largely responsible for the overall performance and strategy of the group; the various spokespersons were expected to formulate and defend the party's policies and strategies in the relevant areas; and the campaign manager was responsible for any advertising the group put out, and was expected to formulate an "official" response from the party to the results of an opinion poll ${ }^{3}$. Given the political constraints on Chinese society, it was also necessary to protect students from doing anything which could potentially cause offence or put themselves at risk of legal consequences. As such, students were explicitly forbidden from discussing any real Chinese political or historical figure, living or dead, and were asked not to discuss any issue in Chinese politics which is considered to be particularly sensitive or controversial, whether that issue is contemporary or historical (e.g. Taiwanese independence, Falun Gong, Uiyghur and Tibetan separatism, etc.). In essence, they were asked to envisage a hypothetical situation whereby the Communist Party had never existed in China, but the country had developed in the exact same manner with a parliamentary system nonetheless. The simulation was conducted over the course of roughly half a semester, and was broken into a series of stages, which are listed in table 1. Prior to beginning the simulation, students were provided with several readings on the basic concepts underpinning the exercise, namely the importance of governmental types, electoral systems, and social cleavages in shaping political outcomes. These were Norris (1997), Morelli (2004), Clark and Lipset (1991), Dalton (1996), and Tsebelis (1995). In addition, the early parts of the simulation coincided with the sections of the course on political party types, thus further helping to prepare them.

Following this, in the first stage of the simulation, the various different parties were asked to come up with a name for their party and a catchy slogan for their party, as well as to assign the various portfolios to each member; students were also advised that their party names should accurately reflect their party archetype (for example, and despite the existence of such a party in Russia, the students were advised that it would not be suitable to call their party the 'Liberal Democratic Party' if they were, in fact, a radical right-wing party). In the second stage, the parties were required to begin formulating their electoral campaign message, and to create a campaign video (or series of campaign videos) which was to be presented in class and on the campus closedcircuit televisions. The third stage was a far more substantial exercise, requiring the participants to devise and disseminate a comprehensive electoral manifesto, detailing the various policies that they would implement should they be in a position to form the 'government'. The various groups were given a great degree of flexibility in terms of the policies they could propose, and were encouraged to devise a plan that they felt would resonate with their electorate (the other students in the class). With that said, they were advised not to stray too far from their archetypal overview;

\footnotetext{
${ }^{3}$ This latter position was somewhat redundant, and the simulation was designed to work with four-person groups; however, given the size of some of the sections, to strictly apply this criteria would have meant the creation of redundant party groups. As such, and in order to maintain clarity within the simulation, it was decided that having redundant roles was less of a problem than having redundant parties.
} 
a green party would have been strongly discouraged from proposing policies that would drastically lower taxes on large, carbon-intensive industries and which would allow fracking in natural reserves, for instance. It is this stage which contained much of the substance of the simulation, as students would need to relate their manifestos to what they understood to be the most salient cleavages in Chinese society, but also to bear in mind the preferences of their electorate. They would then have to try and balance these two issues in such a way that would allow them to successfully fight the campaign, as political parties do in real elections. Following their dissemination of the manifestos to the other participants in the simulation (who were all required to read the manifestos of the other parties), results from an "opinion poll" were presented to the

\begin{tabular}{|c|c|c|}
\hline Date & Stage & Tasks \\
\hline Preparation week & Background reading & $\begin{array}{l}\text { Readings from Norris (1997), } \\
\text { Morelli (2004), Clark and } \\
\text { Lipset (1991), Dalton (1996), } \\
\text { and Tsebelis (1995) }\end{array}$ \\
\hline Week 1 & Party formation & $\begin{array}{l}\text { Assignation of party roles, } \\
\text { unveiling of party names, } \\
\text { mottos, and logos }\end{array}$ \\
\hline Week 2-3 & $\begin{array}{l}\text { Communication of party } \\
\text { messages }\end{array}$ & $\begin{array}{l}\text { Creation of an electoral } \\
\text { campaign video (or series of } \\
\text { videos); the total length of the } \\
\text { videos should not be less than } \\
\text { five minutes }\end{array}$ \\
\hline Week 2-4 & Unveiling of party manifestos & $\begin{array}{l}\text { Creation of a comprehensive } \\
\text { party manifesto, detailing the } \\
\text { party's proposed policies }\end{array}$ \\
\hline Week 5 & Opinion polling results & $\begin{array}{l}\text { Publication of an official } \\
\text { response to an opinion poll } \\
\text { conducted amongst members } \\
\text { of the class }\end{array}$ \\
\hline Week 6 & Elections & $\begin{array}{l}\text { Public presentation of party } \\
\text { manifestos, inter-party } \\
\text { debates, in-class voting }\end{array}$ \\
\hline Week 7 & Government formation & $\begin{array}{l}\text { Formation of coalitions (if } \\
\text { needed), presentation of joint } \\
\text { program for government, } \\
\text { preparation and submission of } \\
\text { response essays }\end{array}$ \\
\hline
\end{tabular}

Table 1: Timeline of the simulation. 
students. This was intended as a 'crisis' moment in the simulation, to see how the students would react and adjust to a change in the information available to them. Students were required to provide a public response to these results, whether it be to disavow the poll as 'fake news', to make a change to their manifesto, to affirm the results and re-assert their manifesto, and so on. The next stage of the simulation involved an in-class debate between the various parties, and an election. In order to ensure that students did not try to 'win' the simulation for their own party, regardless of the merits of their arguments, students were forbidden to vote for their own party. Voting was conducted based on a ranked choice, proportional party list system. With that said, students were not forbidden from coming to formal vote-transferring arrangements with ideologically-aligned parties or with likely coalition partners. ${ }^{4}$ This was permitted on the basis that such horse-trading and deal-making is often a part of the pre-electoral strategies of parties contesting elections in various countries (Golder 2006, 210-211), and students were explicitly encouraged to discuss their usage or avoidance of such strategies in their final assignment. Finally, in the last week, the students were required to work together to form a coalition government (if needed), and to present a joint program for government. Following this, the students were debriefed by the lecturer on the purposes of the simulation, the likely future prospects of the respective parties, and the potential for stability or instability within the governments formed. The students were then asked to write a response paper, explaining their understanding of the events that transpired during the simulation and the reasons for the outcomes of the electoral campaign.

\section{Assessment of the simulation:}

In order to analyze the effectiveness of this simulation as a pedagogical method, data on selfreported learning outcomes and on long-term knowledge and enthusiasm retention was gathered from the students who had completed the role-play simulation. This was measured against a control group of students who had taken the same class in three sections the previous semester (Spring 2016). In order to ensure the validity of the comparisons between the two groups, the course was structured in virtually the same manner in both semesters, with only minor changes being made to the syllabus and to the lectures. These amendments largely consisted of updates of information and some small adjustments to the course readings (but not to the textbook), but were generally fairly inconsequential. No changes were made to the syllabus for the sections of the course on voting systems and governmental types, and minor changes (largely updates of information) were made to the syllabus for the sections on party types. In addition, all assessments and assignments prior to the beginning of the simulation were the same for both groups: they each had the same requirements in terms of class participation, mid-terms, etc. Finally, the demographic make-up of the two groups was largely the same; the students in the course ranged from sophomores to seniors, and none of the students in either group had studied a political science class previously at either WKU or at its 'parent' campus in Kean University, New Jersey. ${ }^{5}$ However, while the test group completed a lengthy simulation which encompassed the majority of the assignments for the rest of

\footnotetext{
${ }^{4}$ Ironically enough, those parties which entered into formal vote-transferring strategies with one another tended to do worse in the simulation; no party with a vote-transferral strategy successfully entered into a governing coalition, and many of them finished in last or second-last position. While this in itself was a noteworthy occurrence, an explanation for why this phenomenon occurred may be somewhat outside the scope of this article.

${ }^{5}$ Indeed, only three students from either group have subsequently taken a political science class, and two of them took that class after the post-test was conducted for their group.
} 
the course, the control group completed traditional assignments including topical essays, presentations, and in-class exams. In each case, the lecturer for both groups was the same.

The data on self-reported learning outcomes was gleaned from SIR II course evaluations ${ }^{6}$ that were assigned to the students at the end of each course. According to Gibson and Shaw (2010), such surveys are often an effective way of gauging active learning outcomes, and of providing direct feedback from students on their feelings about the usefulness of the course and the simulation. In this specific case, such data is being examined in order to analyze the extent to which students perceived the course had helped their learning, the extent to which the course made them think independently, and the extent to which the course encouraged them to actively engage with the learning material. In SIR II evaluations, a composite variable entitled 'course outcomes' is used to measure students' perceptions of learning in these areas. This variable is a composite of responses to five prompts: "my learning increased in this course", "I made progress toward achieving course objectives", "my interest in the subject area has increased", "this course helped me to think independently about the subject matter", and "this course actively involved me in what I was learning". Students are asked on a scale from 1-5 to rate how the course met these outcomes, with 5 meaning that they felt the course achieved these outcomes "much more" than other courses, and 1 meaning "much less". The mean responses for each of these prompts is described in table 2. The composite data is subsequently analyzed using an independent sample t-tests with a $95 \%$ confidence interval, with the data from this described in table 3 on the following page. According to this, the test group reported significantly better learning outcomes than the control group; the

\begin{tabular}{|c|c|c|c|c|}
\hline \multirow{2}{*}{ Prompt } & \multicolumn{2}{|c|}{ Control group (Spring 2016) } & \multicolumn{2}{c|}{ Test group (Fall 2016) } \\
\cline { 2 - 5 } & $\begin{array}{c}\text { No. of } \\
\text { respondents }\end{array}$ & Mean response & $\begin{array}{c}\text { No. of } \\
\text { respondents }\end{array}$ & Mean response \\
\hline $\begin{array}{c}\text { "My learning increased in this } \\
\text { course" }\end{array}$ & 34 & 3.71 & 46 & 3.63 \\
\hline $\begin{array}{c}\text { "I made progress toward achieving } \\
\text { course objectives" }\end{array}$ & 34 & 3.59 & 46 & 3.72 \\
\hline $\begin{array}{c}\text { "My interest in the subject area has } \\
\text { increased" }\end{array}$ & 34 & 3.47 & 46 & 3.72 \\
\hline $\begin{array}{c}\text { "This course helped me to think } \\
\text { independently about the subject } \\
\text { matter" }\end{array}$ & 34 & 3.62 & 46 & 3.83 \\
\hline $\begin{array}{c}\text { "This course actively involved me } \\
\text { in what I was learning" }\end{array}$ & 34 & 3.38 & 46 & \\
\hline
\end{tabular}

Table 2: Mean responses to different prompts on SIR II evaluations measuring self-reported learning outcomes.

\footnotetext{
${ }^{6}$ The SIR II survey is a form of course evaluation created by the Educational Testing Service, and which seeks to “...quickly and objectively captures students' perceptions of their higher education learning experience"

(Educational Testing Service 2019).
} 


\begin{tabular}{|c|c|c|c|c|c|}
\hline \multicolumn{6}{|c|}{ Two-sample t-test with equal variances } \\
\hline Variable & Observations & Mean & Std. Error & Std. Deviation & $\begin{array}{l}95 \% \\
\text { Confidence } \\
\text { Interval }\end{array}$ \\
\hline Control & 34 & 3.576471 & .0133837 & .0780397 & $\begin{array}{l}3.549241- \\
3.6037\end{array}$ \\
\hline Test & 46 & 3.712174 & .0173621 & .1177552 & $\begin{array}{l}3.677205- \\
3.747143\end{array}$ \\
\hline Combined & 80 & 3.6545 & .0136929 & .1224735 & $\begin{array}{l}3.627245- \\
3.681755\end{array}$ \\
\hline Diff & & -.1357033 & .0232592 & & $\begin{array}{l}.1820089- \\
-.0893977\end{array}$ \\
\hline \multicolumn{6}{|c|}{ Degrees of freedom $=78$} \\
\hline
\end{tabular}

Table 3: Independent sample t-test analyzing differences in student self-reported course outcomes between the control group and the test group.

confidence intervals of the two groups do not overlap, the confidence interval of the difference between the two groups does not go through 0 , and the t-statistic is -5.8344 , which is greater than the t-statistic threshold of -1.99 for a sample with 80 degrees of freedom. Additionally, the means for responses to the various different prompts consistently showed the test group reporting better course outcomes than the control group, particularly in the areas of active involvement, progress, and independent thinking. Interestingly, however, the only prompt which elicited a more positive average response from the control group than the test group was on the prompt which asked students to compare the extent to which they felt their learning had increased in Introduction to Comparative Politics, relative to other courses.

In order to assess long-term retention of information and knowledge, students were asked to complete a survey roughly four months after the end of the semester they took Introduction to Comparative Politics (October/November 2016 for the control group, April/May 2017 for the test group). This time delay was implemented in order to ensure that a reasonable amount of time had passed such that one could analyze the level of long-term knowledge retention in each group. The survey asked the students multiple-choice questions about several of the concepts studied in the second half of the semester for both the control and test groups. Again, the results from the two classes were compared using independent sample t-tests, and are detailed in table 4. However, given the lower $\mathrm{N}$ for the post-test as opposed to the pre-test, results are analyzed at both the $95 \%$ and $90 \%$ confidence intervals. According to these results, there is no significance in variation between the control group and the test group at the $95 \%$ confidence interval, but at the $90 \%$ confidence interval the test group had a statistically significantly higher score of nearly one point over the control group on the knowledge retention test. 


\begin{tabular}{|l|l|l|l|l|l|l|}
\hline \multicolumn{7}{|c|}{ Two-sample t-test with equal variances } \\
\hline Variable & Observations & Mean & Std. Error & $\begin{array}{l}\text { Std. } \\
\text { Deviation }\end{array}$ & $\begin{array}{l}\text { 95\% Confidence } \\
\text { Interval }\end{array}$ & $\begin{array}{l}\text { 90\% Confidence } \\
\text { Interval }\end{array}$ \\
\hline Control & 30 & 4.233333 & .3379564 & 1.851064 & $\begin{array}{l}3.542135- \\
4.924532\end{array}$ & $\begin{array}{l}3.659102- \\
4.807564\end{array}$ \\
\hline Test & 49 & 4.979592 & .2359843 & 1.65189 & $\begin{array}{l}4.505114- \\
5.45407\end{array}$ & $\begin{array}{l}4.583793- \\
5.37539\end{array}$ \\
\hline Combined & 79 & 4.696203 & .1976447 & 1.756705 & $\begin{array}{l}4.302722- \\
5.089683\end{array}$ & $\begin{array}{l}4.367198- \\
5.025207\end{array}$ \\
\hline Diff & & & & & $-1.54467-$ & $-1.413809-$ \\
& & -.7462585 & .4009591 & & .0521531 & -.0787079 \\
\hline
\end{tabular}

Table 4: T-tests analyzing differences in post-test results between the control group and the test group, compiled at the $95 \%$ and $90 \%$ Confidence Intervals.

Finally, the level of enthusiasm towards politics and the subject of political science was tested. The results from this are detailed in table 5. In order to ascertain this, students were asked to rate on a scale of 1-10 how they would rate their interest and enthusiasm towards politics, with 1 representing the lowest possible level of interest and enthusiasm and 10 representing the highest level of interest. Again, the mean score of the test group was slightly higher than that of the control group, but in this case, there was no statistically significant difference between the groups.

\begin{tabular}{|c|c|c|c|c|c|c|}
\hline \multicolumn{7}{|c|}{ Two-sample t-test with equal variances } \\
\hline Variable & Observations & Mean & Std. Error & $\begin{array}{l}\text { Std. } \\
\text { Deviation }\end{array}$ & $\begin{array}{l}\text { 95\% Confidence } \\
\text { Interval }\end{array}$ & $\begin{array}{l}\text { 90\% Confidence } \\
\text { Interval }\end{array}$ \\
\hline Control & 29 & 5.793103 & .3824323 & 2.059461 & $\begin{array}{l}5.009726- \\
6.57648\end{array}$ & $\begin{array}{l}5.142536- \\
6.443671\end{array}$ \\
\hline Test & 49 & 6.102041 & .3033892 & 2.123724 & $\begin{array}{l}5.492036- \\
6.712046\end{array}$ & $\begin{array}{l}5.593189- \\
6.610892\end{array}$ \\
\hline Combined & 78 & 5.987179 & .2368722 & 2.091998 & $\begin{array}{l}5.515507- \\
6.458852\end{array}$ & $\begin{array}{l}5.592815- \\
6.381544\end{array}$ \\
\hline Diff & & -.3089374 & .4920699 & & $\begin{array}{l}-1.28898- \\
.6711049\end{array}$ & $\begin{array}{l}-1.128308- \\
.5104336\end{array}$ \\
\hline \multicolumn{7}{|c|}{ Degrees of freedom $=76$} \\
\hline
\end{tabular}

Table 5: T-test analyzing differences in enthusiasm towards the study of politics between control group and test group, compiled at the $95 \%$ and $90 \%$ Confidence Intervals. 
Although this finding runs contrary to that which is described in much of the literature (it is generally found that simulations improve enthusiasm towards the broader field of study within which they are conducted), in this particular case it is perhaps unsurprising. Virtually none of the students in either group have chosen to take a political science class again, and none of the students in either group are Political Science majors. A possible reason for this lack of sustained enthusiasm could be that having no longer continued their learning in political science, and having subsequently focused their attention on other academic pursuits, any enthusiasm gains might have ebbed away by the time the post-test was conducted.

\section{Conclusion:}

It is important not to make sweeping judgments on the effectiveness of this simulation as a tool for increasing active participation and long-term knowledge retention amongst students. Part of the variance between the groups may possibly be explained by the fact that the test group studied Introduction to Comparative Politics at the height of the U.S. Presidential election, whereas the control group only took the class during the Presidential primaries. Given the highly publicized and controversial nature of this election, it is possible that this may have inspired the students to take a greater level of interest in the various policy stances of the respective candidates, and in so doing, to engage more closely with the issues associated with the course. This could potentially explain some of the variance between the two groups. Additionally, while the better performance of the test group than the control group in terms of knowledge retention is significant at the $90 \%$ confidence level, this is not a tremendously strong result, and no significant long-term improvement in terms of enthusiasm towards politics was recorded either. Further testing and replication of the study amongst subsequent classes would need to be conducted in order to allow for firmer conclusions to be made about the simulation's efficacy as a tool for increasing knowledge retention. With that said, the results of the data gathered from student evaluations that measure self-reported learning outcomes are more encouraging. Given that one of the primary motivations behind running the simulation was to encourage students to immerse themselves in and engage more actively with the Comparative Politics, this objective would seem to have been achieved. The test group reported significantly better course outcomes than the control group, with particular improvements in scores measuring active involvement, independent thought, and progress towards achieving course goals. Meanwhile, the results of the knowledge test provide some (admittedly tenuous) evidence that these improvements are not coming at the cost of academic rigor. As such, it does suggest that active learning and role-playing may be a highly effective method of relating Western concepts of political science to a Chinese audience with a low level of background knowledge. Based on this, it is possible to tentatively add this study to the growing literature that demonstrates the effectiveness of simulations and role-play gaming as a pedagogical tool in Political Science. 


\section{Appendix A:}

\section{Knowledge Retention Test}

Question 1: Please indicate in the space provided when and where you took Comparative Politics (PS2300):
a) Fall 2016, [INSERT CAMPUS NAME HERE]
b) Spring 2016, [INSERT CAMPUS NAME HERE]
c) Before Spring 2016, [INSERT CAMPUS NAME HERE]
d) Did not take PS2300 at the [INSERT CAMPUS NAME HERE]

Question 2: Which of these is a policy commonly associated with a green party?
a) The imposition of a carbon tax to lower $\mathrm{CO} 2$ emissions
b) Restrictions on the rights of women to obtain abortions
c) Tax cuts for people earning over $\$ 100,000$ a year
d) Increased military spending and rearmament campaigns
e) None of the above

Question 3: Which of these is a common traditional political cleavage, found in nearly all countries throughout the world?
a) Racial cleavages
b) Agricultural/Industrial cleavages
c) Owner/Worker cleavages
d) Christian/Muslim cleavages
e) All of the above

Question 4: Which of these is a policy that is most likely to be associated with liberal/social democratic parties?
a) Privatization of the health industry
b) Increased welfare benefits for unemployed workers
c) Increased grants to solar energy companies to encourage the development of renewable energy
d) Increased military spending and rearmament campaigns
e) All of the above

Question 5: Which of these is closest to the definition of a proportional electoral system?
a) A system of voting where the winner is the one that gains the most votes
b) A system of voting whereby power is distributed in accordance with the percentage of votes received
c) A system of voting whereby the winning party will receive all decision-making power within the state
d) A system of voting wherein the losing party will receive little or no political representation
e) None of the above 
Question 6: Which of these types of policies is a party with a large proportion of urban-based supporters most likely to favor?

a) Socially progressive policies

b) Socially regressive policies

c) Fiscally redistributive policies

d) Fiscally conservative policies

e) None of the above

Question 7: Which of these is a policy most likely to be associated with a radical right party?

a) Increased delegation of state sovereignty to international organizations such as the United Nations

b) Raising taxes on corporations to ensure they pay their fair share

c) Lowering environmental restrictions on corporations to allow them to function without excessive interference from governmental authorities

d) Restrictions on the numbers of immigrants allowed into the country

e) All of the above

Question 8: Which of these policies is a conservative party most likely to support?

a) Increased taxes on middle- and upper-middle class households

b) Restrictions on access to abortions for women

c) Introduction of relatively generous minimum wage laws

d) Equality of access to marriage for homosexual as well as heterosexual couples

e) All of the above

Question 9: Which of these types of parties would most likely have supported Britain leaving the EU?

a) Liberal political parties

b) Social democratic political parties

c) Green political parties

d) Parties which are most likely to support the interests of major banking companies

e) None of the above

Question 10: Which of these political issues most closely relates to the traditional values/progressive values political cleavage?

a) Increased decision-making power for regional political assemblies

b) Legalization of drugs

c) Increased social welfare spending

d) Abolition of university education fees

e) None of the above

Question 11: On a scale from 1-10, how would you rate your interest and enthusiasm in politics? Please write your number in the space provided $(1=$ lowest possible interest and enthusiasm; $10=$ highest possible interest and enthusiasm) 


\section{Acknowledgements}

Earlier versions of this paepr were presented at the 2017 International Studies Association International Conference in Hong Kong, the 2017 Political Studies Association of Ireland Annual Conference, and the 2018 International Studies Association Annual Convention. The authors wish to thank the organizers of these conferences, and also the panel chairs and discussants. Additionally, the authors wish to specifically thank Gorana Mišić (Central European University), Yuying Liu (University College Dublin), Nela Navarro (Rutgers University-Newark), Toby Michelena (Wenzhou-Kean University), Carolyn Shaw (Wichita State University), Claire Furneaux (University of Reading), Frank Haege (University of Limerick), Mauro J. Caraccioli (Virginia Polytechnic State University), Steven B. Rothman (Ritsumeikan Asia Pacific University), and two anonymous peer reviewers and the ISP editorial team for their valuable comments and assistances. This research was facilitated by a small grant from the Wenzhou-Kean University 'Students Partnering with Faculty' Research Program.

\section{References}

ASAL, VICTOR, AND ELIZABETH L. BLAKE. 2006. "Creating Simulations for Political Science Education.” Journal of Political Science Education 2: 1-18.

ASAL, VICTOR, AND JAYSON KRATOVILLE. 2013. "Constructing International Relations Simulations: Examining the Pedagogy of IR Simulations Through a Constructivist Learning Theory Lens.” Journal of Political Science Education 9: 132-143.

BARANOWSKI, MICHAEL K., AND KIMBERLY A. WEIR. 2015. "Political Simulations: What We Know, What We Think We Know, and What We Still Need to Know." Journal of Political Science Education 11: 391-403.

BIZIOURAS, NIKOLAOS. 2013. "Bureaucratic Politics and Decision Making Under Uncertainty in a National Security Crisis: Assessing the Effects of International Relations Theory and the Learning Impact of Role Playing Simulation at the U.S Naval Academy." Journal of Political Science Education 9: 184-196.

CLARK, TERRY NICHOLS, AND SEYMOUR LIPSET. 1991. “Are Social Classes Dying?” International Sociology 6: 397-410.

DALTON, RUSSELL J. 1996. "Political Cleavages, Issues, and Electoral Change" in Comparing Democracies: Elections and Voting in Global Perspective, edited by Lawrence LeDuc, Richard G. Niemi, and Pippa Norris, 319-342. Thousand Oaks, CA: Sage Publications.

DOUGHERTY, BETH. 2003. "Byzantine Politics: Using Simulations to Make Sense of the Middle East." PS: Political Science and Politics 36: 239-244.

DU-BABCOCK, BERTHA, AND RICHARD D. BABCOCK. 2000. “Adapting an Americanbased Simulation to a Hong Kong Classroom.” Business Communication Quarterly 63: 940.

EDUCATIONAL TESTING SERVICE. 2019. About the SIR II TM Student Instructional Report. Accessed January 29, 2019. https://www.ets.org/sir_ii/about.

FRENCH, HOWARD W., IAN JOHNSON, JERMIAH JENNE, PAMELA KYLE CROSSLEY, ROBERT A. KAPP, AND TOBIE MEYER-FONG. 2017. How China's History Shapes, and Warps, its Policies Today. Accessed July 18, 2018. 
https://foreignpolicy.com/2017/03/22/how-chinas-history-shapes-its-foreign-policyempire-humiliation/.

FOX, RICHARD L., AND SHIRLEY A. RONKOWSKI. 1997. "Learning Styles of Political Science Students." PS: Political Science and Politics 30: 732-737.

GIBSON, KAY, AND CAROLYN M. SHAW. 2010. Assessment of Active Learning. Accessed on March 20, 2019.

http://www.isacompendium.com/subscriber/tocnode?id=g9781444336597_yr2011_chun k_g97814443365973_ss1-8.

GILLEY, BRUCE. 2013. "Using a Virtual History Conference to teach the Iraq War." Journal of Political Science Education 9: 222-235.

GLAZIER, REBECCA A. 2011. "Running Simulations without Ruining Your Life: Simple Ways to Incorporate Active Learning into Your Teaching." Journal of Political Science Education 7: 375-393.

GOLDER, SONA N. 2006. "Pre-Electoral Coalition Formation in Parliamentary Democracies." British Journal of Political Science 36: 193-212.

HING WA SIT, HELENA. 2013. "Characteristics of Chinese Students' Learning Styles." International Proceedings of Economics Development and Research 62: 36-39.

HU, RAN. 2013. "Task-based Language Teaching: Responses from Chinese Teachers of English." TESL-EJ 16: 1-21.

JACKSON, STEVEN F. 2013. "Political Simulations Using Excel.” Journal of Political Science Education 9: 209-221.

JIANG, JIE. 2017. Government leads in patriotic education. Accessed January 29, 2019. http://en.people.cn/n3/2017/1002/c90000-9276195.html.

JONES, KEN. 1995. Simulations: A Handbook for Teachers and Trainers. London: Kogan Page ltd.

LANGFIELD, DANIELLE. 2016. "Reality Imagined: The Choice to Use a Real-World Case in a Simulation.” Journal of Political Science Education 12: 403-419.

LIU, YUYING, FREDA MISHAN, AND ANGELA CHAMBERS. 2018. "Investigating EFL teachers' perceptions of task-based language teaching in higher education in China." The Language Learning Journal: 1-16.

LIU, CAIYU. 2018. China to require patriotism education for intellectuals. Accessed January 29, 2019. http://www.globaltimes.cn/content/1113583.shtml.

LUO, SILING. 2016. Teaching Tiananmen to a New Generation. Accessed July 18, 2018. https://www.nytimes.com/2016/06/22/world/asia/china-tiananmen-rowena-he.html.

MCCARTHY, MARY M.. 2014. "The Role of Games and Simulation to Teach Abstract Concepts of Anarchy, Cooperation, and Conflict in World Politics." Journal of Political Science Education 10: 400-413.

MORELLI, MASSIMO. 2004. "Party Formation and Policy Outcomes under Different Electoral Systems." The Review of Economic Studies 71: 829-853.

MURPHY, MARY C. and THERESA REIDY. 2006. "Exploring Political Science's Signature Pedagogy." Academic Exchange Quarterly 10. Accessed March 20, 2019. https://www.questia.com/library/journal/1G1-159921057/exploring-political-science-ssignature-pedagogy.

NORRIS, PIPPA. 1997. "Choosing Electoral Systems: Proportional, Majoritarian and Mixed Systems.” International Political Science Review 18: 297-312.

OMELCHENKO, DARIA, SVETLANA MAXIMOVA, GALINA AVDEEVA, NATALIA 
GONCHAROVA, OKSANA NOYANZINA, AND OLGA SURTAEVA. 2015. "Patriotic Education and Civic Culture of Youth in Russia: Sociological Perspective." Procedia Social and Behavioral Sciences 190: 364-371.

STOVER, WILLIAM JAMES. 2007. "Simulating the Cuban Missile Crisis: Crossing Time and Space in Virtual Reality." International Studies Perspectives 8: 111-120.

SWITKY, BOB, AND WILLIAM AVILES. 2007. "Simulating the Free Trade Area of the Americas." PS: Political Science 40: 399-405.

TOOMEY, MICHAEL. 2017. Teaching European Political Systems in China. Accessed May 12, 2017.

https://psaiteachinglearning.wordpress.com/2017/05/12/teaching-european-politicalsystems-in-china/.

TSEBELIS, GEORGE. 1995. "Decision Making in Political Systems: Veto Players in Presidentialism, Parliamentarism, Multicameralism and Multipartyism.” British Journal of Political Science 25: 289-325.

UZAKBAYEVA, S., SH. ZHALGASOVA, A. BEISEMBAYEVA, AND G. KOSHERBAYEVA. 2014. "The Patriotism Education Content at the Present Stage." Procedia - Social and Behavioral Sciences 141: 675-679.

VICKERS, EDWARD. 2009. "Selling 'Socialism with Chinese Characteristics' 'Thought and Politics' and the legitimisation of China's developmental strategy." International Journal of Educational Development 29: 523-531.

VOLODZKO, DAVID. 2015. China's Biggest Taboos: The Three Ts. Accessed July 18, 2018. https://thediplomat.com/2015/06/chinas-biggest-taboos-the-three-ts/.

WEIDENFELD, MATTHEW C., AND KENNETH E. FERNANDEZ. 2017. "Does Reacting to the Past Increase Student Engagement? An Empirical Evaluation of the Use of Historical Simulations in Teaching Political Theory." Journal of Political Science Education 13: 4661.

WHEELER, SARAH M. 2006a. "Role Playing Games for Political Science.” Academic Exchange Quarterly 10. Accessed March 20, 2019. https://www.questia.com/library/journal/1G1159921062/role-playing-games-for-political-science.

--------. 2006b. "Role-Playing Games and Simulations for International Issues Courses." Journal of Political Science Education 2: 331-347.

ZHAO, SUISHENG. 1998. "A State-Led Nationalism: The Patriotic Education Campaign in PostTiananmen China.” Communist and Post-Communist Studies 31: 287-302. 